\title{
VIRTUALIZED DEVELOPMENT: ON THE EFFICIENCY OF DIGITAL GOVERNANCE IN LATIN AMERICA
}

\author{
Kirill A. Neverov \\ Saint Petersburg State University, 7-9 Universitetskaya Emb., St Petersburg 199034, Russia
}

\begin{abstract}
The development of information and communication technologies, their active implementation in the practice of political management, over time has made it possible to use the capabilities of the Internet to solve the problems of both managers (making decisions, reducing costs of various kinds) and civil society (accountability of public servants and the government, reducing corruption component). Illustrative here is the existence in many countries of the world of the practice of e-government (e-governance), which, in turn, is one of the stages of digitalization (digitalization) of public administration. For developing countries, the introduction of digital governance is becoming an urgent need due to the flourishing traditions of corruption, nepotism, coups, closed regimes, and the desire to leave the category of developing countries. In addition, the choice of developing countries of Latin America as cases for the study was influenced by the high level of Internet access development in the countries of the region, a large number of users, and high rates of Internet access. The concept of good governance, used by the UN in assessing the quality of governance, is the theoretical basis of the study. Present paper focuses on the study of the introduction of e-governance and digital governance in three developing countries of Latin America: Argentina, Chile and Uruguay.
\end{abstract}

\section{KEYWORDS}

Digital Governance, Developing Countries, Latin America

\section{INTRODUCTION}

The development of information and communication technologies, their active implementation in the practice of political management, over time has made it possible to use the capabilities of the Internet to solve the problems of both managers (making decisions, reducing costs of various kinds) and civil society (accountability of public servants and the government, reducing corruption component). The active use of information and communication technologies in the modern world is associated with developed countries in Europe and Asia, the United States. The Latin America region is less common in scientific articles on the use of ICT technology in public and municipal administration. For Latin American countries, the introduction of digital governance is becoming an urgent need due to a long tradition of corruption, nepotism, coups, closed regimes, and the desire to leave the category of developing countries. In addition, the choice of Latin American countries as cases for the study was influenced by the high level of Internet access development in the countries of the region, a large number of users and high rates of Internet access. The methodological logic of the study is reflected in the following steps.

Step 1 is to identify the literature on the research topic. To accomplish this task, a keyword search is used in the Scopus abstract database, positioned by the Elsevier publisher as the world's largest single database containing annotations and citation information for peer-reviewed scientific literature (Scopus). Search by topic Digital Governance in Developing Countries.

Step 2 is aimed at exploring a modern approach to digital governance and e-governance. At this stage, a review of the literature on the above issues from the number of publications identified during step 1 is carried out.

Step 3 examines the specifics of digitalization of governance in developing countries. The economic, social and political-administrative framework for the introduction and application of digital technologies in the management of developing countries is outlined. The theoretical framework is built on the basis of an 
analysis of the literature on digitalization of management with an emphasis on the features of this process in developing countries, as well as statistical data.

Step 4 is aimed at illustrating the theoretical calculations with examples from the managerial practice of developing countries. The study cases used are Latin American countries - Argentina, Chile and Uruguay. The selection of these cases is determined by the high level of technical and economic development of these countries in the context of the Latin America region, as well as by the rate of computerization and Internetization of the population.

Step 5 seeks to evaluate the effectiveness of digital governance in Latin America. On the basis of studies carried out at earlier steps, such as the analysis of e-government websites in the above-mentioned countries of Latin America, the level of Internetization of the population of the countries of the region, the level of traffic to the websites of e-government of the countries of the region. United Nations E-Government Survey 2018 data is also used.

As a result, it is expected to get a picture of the use of digital governance in developing countries by the example of the Latin American region, as well as to see the level of effectiveness of digital governance in the most developed countries in terms of information and communication technologies in Latin America.

As a theoretical framework for the study, the concept of governance is used, which implies the organization of interaction between society, the state and business. The emphasis in this concept moves from a vertical hierarchy - strictly detailed and regulated - to horizontal ties between government bodies, representatives of civil society, individuals and businesses. Moreover, the opportunity for developing decisions that are significant for society in the concept of governance is increasing due to the fact that management is implemented largely through negotiations between the participants in the interaction, aimed at achieving a result that equally suits all parties involved in the management process, which allows the most efficient way to come to the development of socially significant decisions. This approach allows us to reduce the conflict component, since the process of constant dialogue between stakeholders allows us to increase the level of trust and cooperation, which, in turn, is reflected in changes in the level of transaction costs (in particular, in negotiating with a view to resolving the conflict) towards their reduction, more rational management of resources in common use, as well as a greater degree of openness to innovation (which is justified in the competitive cooperative coopetition model). New technologies in the concept of governance manifest themselves fully, revealing both their own potential and the potential of interaction participants, helping to increase the effectiveness of their joint efforts to work on socially significant problems by eliminating costs: reducing the waiting time for services, eliminating intermediaries in the person of officials, providing Internet platforms for dialogue and exchange of views, accelerating routine processes and making them more comfortable for all interested parties. The digitalization of public administration is precisely that more advanced stage (compared to the concept of electronic government), at which there is a significant reduction in costs associated with the human factor, and the transfer of routine public administration operations to the shoulders of machines. If e-government primarily involves the provision of public services remotely, but with the involvement of public servants, the digitalization of management involves a complete algorithmization of management processes, which significantly reduces the level of official involvement. The theoretical basis of the study also supplied with the concept of good governance, proposed by the UN as a methodology for assessing the quality of public administration. Good governance in this article refers to a system of relations between participants in the decision-making process and the implementation of decisions that meets the following criteria: participation, rule of law, transparency, sensitivity / responsiveness, consensus oriented, equity and inclusiveness, effectiveness and efficiency, accountability (What is Good Governance? United Nations Economic and Social Commission for Asia and the Pacific...)

The classification of the World Economic Outlook International Monetary Fund was used as a working one, dividing the countries of the world into two large groups: "advanced economies" and "emerging and developing economies" (World Economic Outlook. International Monetary Fund). The case studies for this study are Argentina, Chile, and Uruguay. These countries also have high e-Government Development Index (EGDI) indicators, not only at the regional level, but also in the western hemisphere, which allows them to compete with developed countries such as the USA and Canada. 


\section{E-GOVERNANCE AS A STAGE OF DIGITALIZATION}

As of the beginning of March 2019, the Scopus abstract database contains 1020 publications on the request "digital governance", placed in the database from 2005 to 2019, the knowledge industry "Social Sciences". Of these, 633 publications have at least one citation. The five publications in terms of the number of publications are "Government Information Quarterly", "Telecommunications Policy", "Electronic Government", "Transforming Government People Process and Policy" and "European Educational Research Journal". For a query that included the keywords "digital governance latin america", 8 results were obtained between 2005 and 2019. There is one publication in this group with a citation index greater than zero. Publication leaders are the 18th Americas Conference On Information Systems 2012 Amcis 2012, Information Communication and Society, and Latin America Online Cases Successes and Pitfalls. For a query that included the keywords "digital governance developing countries", 65 results were obtained between 2005 and 2019. There are 32 publications in this group with a citation index greater than zero. Publication Leaders - "19th Americas Conference On Information Systems Amcis 2013 Hyperconnected World Anything Anywhere Anytime", "International Conference On Information Systems Icis 2013 Reshaping Society Through Information Systems Design", "Electronic Government", "Transforming Government People Process and Policy" and "20th Americas Conference On Information Systems Amcis 2014." For a query that included the keywords "e-governance", 620 results were obtained between 2005 and 2019. There are 358 publications in this group with a citation index greater than zero. The five publications in terms of the number of publications are "Electronic Government", "International Journal of Electronic Governance", "Government Information Quarterly", "International Journal Of Electronic Government Research" and "Transforming Government People Process And Policy". For a query that included the keywords "e-governance latin america," 2 results were obtained between 2005 and 2019, with quoting above zero from only one of the publications in the Journal of Latin American Geography. For a query that included the keywords "e-governance developing countries", 75 results were obtained between 2005 and 2019, 42 of which cited above zero. The five publications in terms of the number of publications are Electronic Government, International Journal Of Electronic Government Research, Government Information Quarterly, International Journal Of Electronic Governance, and Transforming Government People Process And Policy.

E-Governance can be defined as the use by the government of information and communication technologies (ICT) in order to improve management, increase its effectiveness. According to Saxena, E-Governance is an evolved management in the traditional sense that has evolved into an information age management model whose goal is to implement management processes and structures using ICT potential at various levels of government and the public sector to ensure good governance (Saxena, 2005). However, the concepts of e-governance and e-government should not be confused. E-Government is defined by researchers as "communication between the government and its citizens through computers and web presence" (Evans, D., Yen, D. C., 2006); government use of web-technology to provide citizens and businesses with information and services, customer-oriented electronic services that have strictly utilitarian applications, which is determined by the use of high-tech initiatives to improve services, administration and management (Dawes, S. S., 2009). There are 4 groups of e-government: G2C (Government to Citizen), G2B (Government to Business), G2G (Government to Government) and IEE (Intra-government). Thus, E-Government is an institution, while e-governance acts as a broader concept that describes forms of leadership that may be in the hands of not only formal government (Saxena, 2005).

Digital governance (digital-era governance) refers to changes in management systems and methods of interaction with citizens and other representatives of civil society. ICTs play a central role in these changes, supporting and integrating current bureaucratic adaptations. At the same time, the changes are not only of a technological nature, influencing how management is technically carried out, but they also act through a spectrum of cognitive, behavioral, organizational, political and cultural changes related to information systems in a broad sense (Dunleavy, P., Margetts, H. , Bastow, S., Tinkler, J., 2006).

Lisa Welchman defines digital governance as the basis for building the accountability, roles and system of authorities that make decisions to ensure the digital presence of the organization (websites, versions of web sites for mobile devices, social channels or any other products and services that support web and Internet technology ) (Digital Governance).

The Digital Governance Initiative refers to digital governance as digitalization and ensuring the accessibility of information, on the basis of which decisions are made, both to decision-makers and ordinary 
citizens. Access to information and knowledge officially recognized by decision-makers and citizens is provided through wed 2.0 technology (Digital Governance). At the same time, DGI experts put an equal sign between digital governance and e-governance, talking about the latter as a more popular synonym for digital governance.

The introduction of e-governance and digital governance have their own characteristics in developing countries due to the specifics of political and administrative, sociodemographic and economic conditions. In developed countries, public sector reform took place from within, while in developing countries, this process was initiated externally by organizations such as the World Bank or the IMF. The political and administrative features of developing countries also include a high level of bureaucratization and centralization of public administration, and the corruption of power and management structures. The overall level of democratization for developing countries also remains low. Moreover, Latin America is the region of the world with the highest level of democratization among developing countries (The Economist, 2018). Chile and Uruguay selected as objects for a case study in the Global Democracy Ranking - 2016 ranking are at 24 and 21 positions, respectively, which puts them on a par with such developed countries as Portugal (20), Latvia (22), Estonia (23) and Czech Republic (25). Argentina is out of line, located between Hungary (42) and Brazil (44) (DemocracyRanking). In socio-demographic terms, parameters such as age, gender, educational level, income distribution, linguistic diversity and the percentage of the population living in rural areas are key in terms of acceptance and the ability to take advantage of those that provide e-governance and digital governance. The median age in the world is 30.6 (Central Intelligence Agency). This indicator for Latin America is 29.5 (WorldoMeters). Particularly important for this study is the percentage of urban and rural population. While developing countries are generally characterized by a preponderance towards the rural population, Latin American countries are characterized by a predominance of urban population: $80.4 \%$ of Hispanics live in cities (WorldoMeters). The language factor is not a problem: the official languages are Spanish and Portuguese. The level of economic development in developing countries is traditionally low, the economy is often dependent on external investmentsIn terms of GDP, Argentina ranks 21 positions in the World Bank GDP Ranking - 2017, between Switzerland (20) and Sweden (22), Chile takes 41 lines between Pakistan (40) and Finland (42), Uruguay is located 78th between Costa Rika (77) and Croatia (79) (World Bank). While the process of digitalization of public administration for developed countries is generally painless for the economy, for developing countries, innovation is a serious and risky step requiring high costs and a long payback period. Developing countries have to overcome obstacles such as: a high level of interdependence of digital technologies, requiring the construction of a wide ecosystem; comprehensive leadership and high institutional capacities in the ICT sector for planning and implementing digital transformation strategies; Long-term investments in organizational capacity, process improvement and training.

\section{CASE STUDY SECTION}

One of the essential aspects of a person's presence in virtual reality is the possibility of creating a more advanced system for managing social and political processes. An individual included in cyberspace today receives public services, influences public policy and participates in elections much faster and more efficiently than if he did not use the opportunities that Internet technologies provide. The thinking of a person of the digital era, "digital thinking", is faster, able to process more information per unit of time, work in multitasking mode, which undoubtedly outperforms "analogue thinking". In modern realities, the government system, as well as business, adjust to the accelerating pace of a new type of thinking, transferring part of its activities into the virtual sphere. Illustrative here is the existence in many countries of the world of the practice of e-government (e-governance), which, in turn, is one of the stages of digitalization (digitalization) of public administration. The introduction of personal id and biometric passports into practice reduces the costs of both an individual citizen who uses public services and allows public authorities and organizations that provide public services to possess all the necessary information. The use of technology of distributed registers in the case of public administration allows you to increase trust in the network (if you imagine the system of providing public services in the form of a political network), reduce transaction costs, make political processes more transparent, thus allowing to reduce costs such as corruption, nepotism, extortion. The development of information and communication technologies, their active implementation in the practice 
of political management, over time has made it possible to use the capabilities of the Internet to solve the problems of both managers (making decisions, reducing costs of various kinds) and civil society (accountability of public servants and the government, reducing corruption component). The development of information and communication technologies in the modern world is associated with developed countries in Asia, Europe and the USA. Developing countries are less commonly mentioned in scientific studies on the use of ICT technology in public and municipal administration. For countries of such countries, the introduction of digital governance is becoming an urgent need due to the flourishing traditions of corruption, nepotism, coups, closed regimes, and the desire to leave the category of developing countries. In addition, the choice of developing countries as cases for the study was influenced by the high level of Internet access development in the countries of the region, a large number of users, and high rates of Internet access.

The study examined three cases of the introduction of e-governance and digital governance in political governance: Argentina, Chile and Uruguay.

\subsection{Argentina}

In Argentina, significant advances towards the introduction of digital government have been made since 2015. President Mauricio Macri initiated the creation of the Ministry of Modernization (Ministerio de Modernización). The Ministry of Management includes the Laboratory of Management (Laboratorio de Gobierno), whose task is to develop services for joint creation of decisions in the field of public policy (El Laboratorio de Gobierno). In September 2018, the government was reorganized, which led to the renaming of the Ministry of Modernization into the Government Secretariat of Modernization (Secretaría de Gobierno de Modernización, SGM). The secretariat entered the cabinet under the supervision of Prime Minister Marcos Peña. This step allowed the Secretariat to take a position at the intersection of several policy areas, which will reduce the risk of fragmentation and ensure the sustainable implementation of the task of digitalizing governance in the country. It is also a sign that this direction is significant for the current government of the country. In 2016, the Plan País Digital plan was launched. The plan was aimed at improving the quality of services, promoting transparency and promoting digital inclusion of citizens. The main objectives of the Plan were identified:

- Implementation of digital projects, products and services that contribute to the modernization of the provincial government, municipal government and the autonomous city of Buenos Aires;

- Integration of the management system between different jurisdictions, facilitating the exchange and transparency of information;

- Formulating governance and digital services initiatives with representatives from the private sector, academia, civil society and local communities (Gobierno de Argentina).

In November 2018, a 2030 Digital Agenda (Agenda Digital "2030") was approved by presidential decree. The agenda was designed to create a single vision and roadmap for digitally transforming Argentina, which will achieve digital inclusion for all citizens ("zero digital poverty") and a more effective, efficient, citizen-driven public sector that works better at lower costs. The agenda also seeks to improve the productivity and competitiveness of the economy. The 2030 Digital Agenda involves the use of digital technology with an emphasis on economic development, the digital inclusion of all Argentines and the creation of an effective and citizen-oriented government. The document sets priorities and gives impetus to initiatives related to promoting a legal framework that allows using digital opportunities, promoting the development of telecommunications infrastructure for universal access to the Internet, promoting digital literacy as a driving force for inclusiveness and effective development of the government (El Boletín Oficial de la República Argentina). At the moment, through the digital government today you can perform more than 1200 procedures in digital form, you can create a company in 24 hours and online, simplify the processes of foreign trade. There is access to more than 3,500 digital tools, such as web pages and control panels, they have been implemented in municipalities, an electronic document management system has been introduced in all national ministries and 184 government agencies, where internal procedures are already $100 \%$ digital (Gobierno de Argentina). 


\subsection{Chile}

Although in Chile, Cybersyn, the economic management information system operating in the early 1970s, was the first experience in introducing information technology into management, in the modern period of the country's history, digitalization steps were launched in 2013 with the adoption of the Digital Agenda for Chile. In 2015, this project was restarted under the name Digital Agenda 2020 (Agenda Digital 2020). The digital agenda for Chile (Agenda Digital 2020) covers areas such as expanding the use of online services, supporting the development of industry policies through the use of ICTs, strengthening a more open and transparent state and promoting innovation in the public sector. The document defines medium-term goals, lines of activity and specific measures that are developed by various ministries and state institutions to achieve their specific goals. The Government sees the Agenda as a tool to disseminate, coordinate and facilitate monitoring and measuring the progress of actions taken. The process of adopting a national digital agenda provides for responsibility for its planning by the Ministry of Economy and budgeting issues by the Ministry of Finance. The strategy is formulated around 60 priorities and includes a chapter on digital government with four main lines of action, for a total of 18 measures (Digital Government in Chile). Government services are provided at https://digital.gob.cl/.

\subsection{Uruguay}

In Uruguay, the digitalization of the full range of public services by 2020 has been declared a presidential goal. Through standardization, services such as electronic forms, notifications, payments were digitalized using common and reusable components, making the services more user-oriented. Government services are provided by https://www.gub.uy/. Through an electronic signature integrated into an identity card or a unique pair of "User ID - password", a citizen can access all public services on the basis of a "single-sign-in" principle. Coordination is carried out by the Agency for Electronic Government, the Knowledge and Information Society (Agesic) from the office of the President. In addition to developing the "Digital Government Plan for 2020," the Uruguayan government has developed the "Uruguay Digital Technology Agenda 2020," a plan based on four main pillars: 1) social policy and integration, 2) sustainable economic development, 3) state management, and 4) the management of the information society. Agenda VI's "Close Governance" Agenda aims to increase transparency, accountability, citizen participation and the provision of services by increasing attention to citizen engagement with the government. Specific goals include the creation of "Citizens Response Centers" and portals that will allow citizens to complete all transactions related to certain services online (Department of Economic and Social Affairs. Public Institutions).

To evaluate the effectiveness of digital governance in Latin America, the data of the UN E-Government Survey 2018 (Department of Economic and Social Affairs. Public Institutions). Argentina, Chile and Uruguay have the value of the UN E-Government Development Index (EGDI), respectively:

- 0.7335 for Argentina;

• 0.7350 for Chile;

- 0.7858 for Uruguay.

Argentina and Chile fall into the group of countries with high levels of EGDI, while Uruguay is even higher in the group of countries with very high levels of EGDI, which also include the United States and Canada.

\section{CONCLUSION}

Thus, we can conclude that the developing countries of Latin America as a whole are effectively implementing a digital governance strategy in terms of efforts made by government bodies to develop and implement digital technologies in public administration, designed to simplify and make attractive the process of obtaining state services from any point where there is Internet access 24 hours a day and 7 days a week. The Latin American Society is prepared for large-scale digitalization: with an extremely urbanized young population susceptible to innovation, government-backed Internet access, training programs and access to digital gadgets, among developing regions of the world, Latin America has been using ICTs in the field of public services with high efficiency and effectiveness. and municipal governance in accordance with the 
principles of good governance. A distinctive feature of the Latin American approach to digitalization of public administration is planning, the concentration of initiative in the hands of the government, if the center has a desire to listen to business and civil society. Despite the problems of a political, economic and social nature, Latin America is moving forward in transforming public administration in order to increase its effectiveness, transparency, accountability and citizen involvement.

\section{ACKNOWLEDGEMENT}

The author disclosed receipt of the following financial support for the research, authorship, and/or publication of this article: This work was supported with a grant from the Russian Science Foundation (grant 19-18-00210 "Political ontology of digitalization: Study of institutional bases for digital forms of governability").

\section{REFERENCES}

Central Intelligence Agency. The World Factbook. URL: https://www.cia.gov/library/publications/resources/the-worldfactbook/fields/343.html

DataBank. URL: https://databank.worldbank.org/data/download/GDP.pdf

Dawes, S. S., 2009. Governance in the digital age: A research and action framework for an uncertain future. In Government Information Quarterly, Vol. 26, № 2, pp. 257-264

Democracy Ranking. URL: http://democracyranking.org/wordpress/rank/democracy-ranking-2016/

Department of Economic and Social Affairs. Public Institutions. URL: https://publicadministration.un.org/egovkb/Portals/egovkb/Documents/un/2018- Survey / E-Government\% 20Survey\% 202018_FINAL\% 20for\% 20web.pdf

Digital Governance. URL: http://www.digitalgovernance.org/index.php/concept

Digital Governance. URL: https://digitalgovernance.com/dgblog/what-is-digital-governance/

Digital Government in Chile: Strengthening Institutional and Governance Frameworks. URL: https://www.sicexchile.cl/portal/documents/10180/16900/digital-government-in-chile-version-24-316.pdf/433c2812-5599-4a74-82ff-3da349a2a557

Dunleavy, P., Margetts, H., Bastow, S., \& Tinkler, J., 2006. New public management is dead - long live digital-era governance. In Journal of Public Administration Research and Theory, Vol.16, №3, pp. 467-494

El Boletín Oficial de la República Argentin. Gobierno de Argentina. URL: https: //www.boletinoficial .gob.ar / \#! DetalleNorma / 195154/20181105

Evans, D., Yen, D. C., 2006. E-government: Evolving relationship of citizens and government, domestic, and international development. In Government Information Quarterly, Vol.23, №2, pp. 207-235

Gobierno de Argentina. URL: ttps: / /www.argentina.gob.ar/noticias/el-gobierno-presento-la-nueva-agenda-digital-2030;

Gobierno de Argentina. URL:https://www.argentina.gob.ar/node/4462

International Monetary Fund. World URL: https://www.imf.org/external/pubs/ft/weo/2018/02/weodata/groups.htm

La Agenda Digital 2020. Gobierno de Chile. URL: http://www.agendadigital.gob.cl

Laboratorio de Gobierno. Gobierno de Argentina. URL: https://www.argentina.gob.ar/laboratoriodegobierno;

Saxena, K.B.C., 2005. Towards excellence in e-governance. In International Journal of Public Sector Management, Vol.18, №6, pp.498-513

Scopus. URL: http://www.elsevierscience.ru/products/scopus/

$\begin{array}{llllll}\text { The } & \text { Economist } & \text { Intelligence } & \text { Unit } & \text { Democracy } & \end{array}$ URL: https://www.eiu.com/public/topical_report.aspx?campaignid=Democracy2018

United Nations Economic and Social Commission for Asia and the Pacific. What is Good Governance? URL: https://www.unescap.org/sites/default/files/good-governance.pdf;

WorldMeters. URL: http://www.worldometers.info/world-population/latin-america-and-the-caribbean-population/

WorldMeters. URL: http://www.worldometers.info/world-population/latin-america-and -the-caribbean-population / 